\title{
An Essay about Development of Public Policies on Social Rights in Brazil: Between Human Rights, Dignity, and Grounds for Governance
}

\author{
Rafael Seixas Santos \\ Professor of Law Department (IESB - Instituto de Educação Superior de Brasília; UDF \\ - Centro Universitário do Distrito Federal), Brasília, Brazil.
}

Received: June 12, 2018 Accepted: July 5, 2018 Online published: July 16, 2018

doi:10.5296/jpag.v8i3.13389ＵRL: https://doi.org/10.5296/jpag.v8i3.13389

\begin{abstract}
The implementation of social rights through public policies may be validly justified in the discussion of human rights. The public policies for the area are important factors in the development process and to the governance of public actions in the sector. Nonetheless, those policies are not often formulated or voluntarily produced by the public power due to lack of planning, budgetary nature, or even the lack of effective and practical's recognition as grounds for a complete elucidation of the human rights development. Then, human, social and economic rights in Brazil and its political-juridical importance can be investigated by the possibility and effectiveness of the invocation of human dignity as a foundation. This way, it must offer an alternative to the development crisis of this category of rights to the Brazilian state.
\end{abstract}

Keywords: public policies, Brazil, human dignity

\section{Introduction}

The implementation of social rights through public policies (executed under economic law arrangements) is validly justified in the discussion of human rights, which, by assuming the status of fundamental rights, have immediate application and a broad relation with the dignity of the human person - one of the foundations of the Federative Republic of Brazil and a core element of citizenship.

It is a fact that the public policies for the area are important factors in the development process and to the governance of public actions in the sector. It occurs because public policies for the full exercise of these rights are seen in practice as socioeconomic, so they are not often formulated or voluntarily produced by the public power. 
This lack of effectiveness in the public power's action occurs due to lack of planning, budgetary nature, or even the lack of effective and practical's recognition as grounds for a complete elucidation of the human rights development and, even more, of social rights, especially because they contain provisions of an economic nature (SANTOS, 2016).

The absence of adherence or harmonization in regarding the recognition of the justifying arguments of all social and economic rights (as inherent in human dignity) seems to contribute to the inertia in the formulation and implementation of public policies, which are aimed at ensuring their applicability.

On this hypothesis, it can be seen that there is no way to guarantee citizenship without dignity, and there can be no true dignity without the minimum individual economic guarantees and, even less, without social rights - to be materialized by state actions: in public policies.

It is common ground to understand that the promotion and development of rights produce economic repercussions in the realizing process of human dignity. It is also noted that these rights have undergone of a process elevation or reinterpretation caused by to advances in the social field and in the so-called "quality of life", at least theoretically.

In effect, these kinds of rights are not merely instruments of citizens' social insertion, but they are true mechanisms of the effectiveness of human dignity and, in the end, of development's promotion and improvement of the governance mechanisms.

Because the shortcoming in the justification and application of human and social rights by economic mechanisms, and by the implementation of political actions, it implies to assert how rights can find a foundation in dignity, so that they routinely (and not judicially) compose the public policy agenda. It happens especially when the implementation of those rights, on several occasions, is possible only in the judicial process, in a judicial distributive justice.

Thus, this text seeks to assess broadly and panoramically the hypothesis of grounding government policies on human and social rights in elements of public policy, and thus economic approaches.

The discussion also goes on to see how these rights are founded on dignity, given their conceptual association. Therefore, the interfaces and dichotomies between public policies and their adoption mechanisms in the satisfaction of rights by the natural actors (Public Power) and by the secondary route (Judiciary), always in the search for development, must be, as soon, analyzed.

\section{The Development of Policies for Social Rights: The Protection of Dignity Recognition}

It is a well-known fact that the implementation of public policies - in general - is an important factor to give pragmatism to the development discussion. However, one of the most significant problems in this field is the way of justifying public action. That is why this paper points to dignity as the protection of public actions aimed at the realization of social rights, through public policies. 
The Brazilian legal and social context shows that there is still a wide field for the realization of all the rights established in its Constitution and shows, as well, a considerable challenge for the governments of the Federated States to make them viable over time.

It is clear from recent Brazilian history that political democracy has not been able to solve the most serious economic problems, such as income inequality and unemployment (CARVALHO, 2001, p.199).

What is perceived, indeed, is the realization of some economic rights against other kinds of social rights or, worse, the neglect of the fulfillment of certain rights due to lack of public policies that ensure their effectiveness - eroding components of citizenship.

That gap becomes more noticeable when one takes into account the concept of efficiency, a measure that will be adopted in the text according to the following approach:

Against the idea that law can be understood only through the use of traditional legal doctrinal concepts based on justice and fairness, economics counters that such understanding can be augmented by economic concepts, including the criteria of economic efficiency. (POSNER, 1990, p.84).

On a more concrete plan, it can be seen from the Brazilian political and legal design that public policies are the primary link between the constitutional plan and the realization of human and social rights that demand economic measures. This occurs in search of production of the said 'efficiency'.

In fact, public policies, as enforcement mechanisms, are their own guarantee (MASSA-ARZABE, 2006) and are thus aimed at rationalizing the state collective benefits, it happens in order to meet social desires and promote distributive justice, inherent in the very nature of human rights fundamentality economical character.

As already mentioned, the formulation and implementation of public policies that seek to satisfy the rights claimed by society, by norms of economic law, are not always complete. Sometimes it is necessary for the Judiciary to recognize the right (through judicial provision) to coerce public policy formulations and governance.

From another angle, the importance that the concept of the dignity of the human person has been naming as a political, philosophical and juridical precept has recognized the principle as one of the rights foundations. In this framework, there is no way of forgetting the Kantian idea, according to which dignity differentiates the rational being from others and, by giving it autonomy, makes the individual capable of self-determination (KANT, 2004).

In order to place dignity as a principle and scope of interpretation, one must imagine a subject endowed with intrinsic value, who has guarantees that honor him as an end in itself, despite the consequences that his actions (or omissions) may bring to society of which it is part, since the individual carries an end in itself (COSTA NETO, 2014). Because this relevant value, it is possible to discuss this ground adoption by the public policies area.

Indeed, dignity, as an anchor principle of rights, must rest in a political and comprehensive 
view, in order to construct a measured conception that dignity is an instrument of the normative dimension evaluation about the Constitution. That is possible supposing the function of founding the Order Juridical and Economic Order, being, even, a source of observation and integration (BONAVIDES, 2011, p.105).

In the context of social interests, specifically in the search for consensus for the decision of the level of intensity of execution of the public action, that law emerges as a tool to be satisfied, to reconcile and harmonize, to adjust the (often) conflicting demands of society. And the interpretation of the law, in the exercise of the judges/courts, through the basics of the judicial provision, can act guaranteeing:

The expansion or contraction of the legal system to reach these goals is what we call judicially declared public policy. So perceived, social consensus demands sympathy from the court. Where the legislature has not acted in accordance with changing social policies and seemingly does not so intend to act, the courts have not only the authority but possibly the duty, to keep pace with the change in consensus. (ALDISERT, 2009, p.2).

Thus, one of the most difficult fields in the sphere of human dignity is its conceptualization and assimilation as the foundation for the rights that demand economic contributions.

\section{Public Policy Rights: Governance in Economic and Social Law Texts and Procedures}

As the holder of dignity boasts rights and demands justification, the expansionist conception of those rights has raised them to universality, surpassing the domestic plane.

So that the scenario becomes more complex as the internationalization movement intensifies and through it pass the torrents of mechanisms and means of promoting human rights by the deconstruction of individualistic values.

The Declarations - notably the Universal Declaration of 1945 and the International Covenant on Economic, Social and Cultural Rights of 1966 - led to a new agenda of claims for notably political and economic freedoms and rights.

In other words, the abstract universalism of the Declarations imposes its consequences: the idea of general announcements, of taking care of the general, and sometimes of the individual. It is not ignored, however, that, in a socially and in an opposite sense, private values start to stand out in the face of collective values (VIEIRA, 2008).

So, the generalizations of the Declarations positive aspects have raised awareness of the rights of minorities, namely, blacks, women, children, villagers ... That must be led to the recognition of rights advances, in development of "citizens' rights", then "who votes against the rights of others, whatever their religion, color or sex, from that moment abjured their own rights" (HUNT, 2009, p.171).

In search of elements to inform the interpretation that is being constructed important to assume that individual autonomy supports the notions of freedom and of rights. Therefore, it is found that freedom is the driving force for equality, so that, in the same chain, "Everyone 
would have rights only if everyone could be seen, in an essential way, as similar" (HUNT, 2009, p.26).

According to Alves (2003, p. 115), the rights demand economic measures and all human rights promote alteration of the status quo, both in the international sphere and in the states internal orbit.

There is also the idea of Herrera Flores (2008), a proponent that we cannot understand rights without seeing them as part of the struggle of social groups committed to promoting human emancipation. Symmetrical position to Beitz (2009) and Donnelly (2013), who states:

Human rights thus provide the moral standard of national political legitimacy. They are also emerging as an international standard of legitimacy. More precisely, the full legitimacy of regimes that grossly and systematically violate human rights is widely seen as compromised. (...) We have human rights not to what we need for survival but what we need for a life of dignity (Donnelly, 2013, p.21/23).

For this reason, the international cultural change, although gradually, and asserts that the Institutions should advocate the guarantee and promotion of rights, especially those of an economic nature, just to legitimize the appearance of the expression of governance in state actions.

This fact stems from the growing pressure from domestic and international organizations to promote and 'enforce' human rights: "Human rights organizations claim that they respect human rights and allied with international human rights networks to publicize human rights violations and demand change" (LUTZ, SIKKINK, 2000, p.635).

In this way, a historical perspective of the recognition of the rights by the Brazilian democracy is woven from the necessary internal incorporation of the economic rights, encapsulated by Trindade (1990), Bagnoli (2005) and Piovesan (2012).

Therefore, it is possible to discuss innovative perspectives of interpretation and construction of meanings, just to foster the dynamics of institutionalization, allow to synchronize the actors' procedure in the fulfillment of public policy objectives, at least normatively (FLIGSTEIN, 1997).

At least, it is possible to debate about one way to conjugate the constitutional text whit the public policies through the public actions and governance humanization.

\section{Social and Economic Rights: Humanization as a Bridge between the Constitutional Text and Public Policies}

The Brazilian Constitution employs dignity to repel any aggression against the human being in order to avoid imprisonment, torture, ill-treatment and any other form of violation of individual autonomy, even in procedural terms.

The central argument of the text is the lofty principle embodied in article 1, item III of Constitution, as the source value that confirms the entire constitutional system in force in the country. That happens because: 
The constitutional political economy is a research program that directs to the working properties of rules, and institutions within which individuals interact, and the processes through which these rules and institutions are chosen or come into being. (BUCHANAN, 1990, p.1).

From this context, Bercovici's (2005) proposal emerges to understand and apply the Constitution as a systematization of the legal configuration of the Economic Order and the mechanisms of state action in the economic domain, with the clear function of social transformation, through the prediction tasks and measures to be undertaken. In the same sense obsolete Cardozo (2011), and teaches Trindade (1997).

The idea is to give maximum effect to the human person protection, through the systematization of dignity as a foundation. Thus, human rights can be promoted by virtue of the personal conditions of its holder because, according to the systematic interpretation of the constitutional text, this measure promotes the dignity of the human person.

In its turn, the norms of economic and juridical nature, by express provision of the text of the Brazilian Constitution, and because they derive from an Economic Order based on notably humanistic postulates, pursues social justice. With such a conceptual approach, dignity is used to justify the most diverse situations, through a process of "symbolic constitution" (NEVES, 2012, p. 87).

The recurrent use of the "dignity" foundation, both in the constitutional text and in the Brazilian Supreme Court, and in the most diverse political arenas, contributes to its increasing use and to its invocation in the various social spheres (for example, read SANTOS, 2016). This is the context in which citizens should be considered in relation to the set of unequal positions that people and groups occupy in the social strata (HERRERA FLORES, 2008, p.96).

When the autonomy of the individual undergoes threats of consideration that have the power to lessen the conditions of survival, there is a break in his wake of dignity, a violation of his economic human rights. This demands a valiant and protected concept of founding dignity:

[...] They [the people] have a right to be treated with an attitude that these debates presuppose and reflect - a right to be treated the human being whose dignity fundamentally matters. That is the right human being. (DWORKIN, 2011, p.335).

However, the scenario of judicial defense of rights, including the demand for the publication of juridical end economic norms, occurs because public policies for implementation and exercise these rights, on several occasions, do not emanate voluntarily from the Public Authorities (Executive or Legislative): Arguments of planning, of financial reserves, or even the absence of pragmatic foundations for a complete implementation of human rights in the framework of economic norms are invoked by the authorities.

The application of economic human rights - especially when their implementation is possible only in the judicial process - is a mechanism capable of making the human-economic rights judicial process as a natural theme of the public policies agenda. 
Given the non-effectiveness of the Public Power in promoting human-economic rights, the individuals or institutions that represent them resort to the Judiciary that, as an instance in which the final hopes are placed and, in an inflation of legitimacy, promotes justice in the determination of public policies.

In this sense, public policies must be known (if they exist) or required (if absent) by the Judiciary, when they can be effectively guaranteed because in this way it would be possible to combine individual interests with the collective ones of the Government.

As unconventional as it may sound, it is through the formalization of economic human rights by determining the implementation of such policies by judicial provision when one obtain justice have promoted his citizenship.

For this reason, the Judiciary presents the heavy challenge of demystifying and incorporating the semantic load of public policy in its decisions, in the sense of making justice compatible, within each concrete case, with the distributive justice, represented by the collective decision formulated by actions promoted (or that should be promoted) by the Legislative and Executive Functions of the state. Here, a secondary link emerges between economic (constitutional) human rights and their realization: judicial provision (RIPLEY, 1995).

It is within this context of the constitutional "human-economic" norms and their non-fulfillment effectiveness that prioritization of rights and scarcity of resources must integrate the discussion about the invocation of dignity as a foundation for economic rights.

\section{Conclusions}

The text highlights the context of human rights political measures, social security and economic development through the establishment of dignity as the foundation of these rights. It covers the debate about the emergence of governance standards in relation to public action in that sector.

Human rights have immediate application and are broadly related to the dignity and include provisions of an economic nature. In this way, the importance that the concept of human dignity has been naming as a political, philosophical and juridical precept has recognized the principle as one of the foundations of human, social and economic rights.

However, public policies for these rights implementation and exercising, on several occasions, do not emanate voluntarily from the Government, for various reasons, such as planning, budget, empty speeches, etc.

The Brazilian scenario is, although judicially, challenging with regard to the feasibility of 'human-economic' rights: the foundation of dignity demands measures, by virtue of those rights expansionist conception, which raised them to universality, surpassing the domestic plane.

With the sum of diverse theoretical perspectives, one can promote the adoption of positions that facilitate the capitulation of transposable legal elements to the universe of public policies (SUNSTEIN, 2009). 


\section{Macrothink}

Journal of Public Administration and Governance ISSN 2161-7104 2018, Vol. 8, No. 3

Therefore, exploring human, social and economic rights in Brazil and its political-juridical importance by investigating the possibility and effectiveness of the invocation of human dignity as a foundation can offer an alternative to the development crisis of this category of rights - notably due to the historical difficulty on establishing effective public policies by the Brazilian state.

\section{References}

Aldisert, R. J. (2009). Judicial Declaration of Public Policy. J. App. Prac. \& Process, 10, 229.

ALVES, L. Direitos humanos como tema global. Ed: 2a . São Paulo: Perspectiva, 2003.

Bagnoli, V. (2013). Direito Econômico. Ed: 6ª . São Paulo: Atlas.

Beitz, C. (2009). The idea of human rights. Oxford: OUP. https://doi.org/10.1093/acprof:oso/9780199572458.001.0001

Bercovici, G. (2005). Constituição econômica e desenvolvimento: uma leitura a partir da Constituição de 1988 (p. 147). São Paulo: Malheiros Editores.

Bonavides, P. (2011). Curso de Direito Constitucional - São Paulo. Malheiros. 26 a Ed, p.105.

Buchanan, J. M. (1990). The domain of constitutional economics. Constitutional political economy, 1(1), 1-18. https://doi.org/10.1007/BF02393031

Cardozo, J., Eduardo, M., Queiroz, J., Eduardo, L., Santos, M., \& Walquiria, B. dos (Coord.). (2011). Direito administrativo econômico. São Paulo: Atlas.

De Carvalho, J. M. (2001). Cidadania no Brasil. O longo caminho, 18, 18.

Costa Neto, J. (2014). Dignidade humana: visão do Tribunal Constitucional Federal Alemão, do STF e do Tribunal Europeu. São Paulo: Saraiva.

Donnelly, J. (2013). International human rights. Westview Press.

Dworkin, R. (2011). Justice for hedgehogs. Harvard University Press.

Fligstein, N. (1997). Social skill and institutional theory. American behavioral scientist, 40(4), 397-405. https://doi.org/10.1177/0002764297040004003

Herrera, F. J. (2008). La reinvención de los derechos humanos. Andalucía: Atrapasueños.

Hunt, L. A. (2007). Inventing human rights: A history. WW Norton \& Company.

Kant, I. (2004). Fundamentação da metafísica dos costumes e outros escritos. tradução de Leopoldo Holzbach. São Paulo: Martin Claret.

Lutz, E. L., \& Sikkink, K. (2002). International Human Rights Law and Practice in Latin America in International Organization, 54(3), 633-659.

MASSA-ARZABE, P. H. (2006). Dimensão jurídica das políticas públicas. Políticas públicas: reflexões sobre o conceito jurídico. São Paulo: Saraiva, 51-74.

Neves, M. (2012). Abuso de princípios no Supremo Tribunal Federal. Observatório 
Constitucional, 27.

Piovesan, F. (2012). Direitos humanos e o direito constitucional internacional. Saraiva.

Posner, R. (1990). The Problems of Jurisprudence. Harvard University Press.

Ripley, R. B. (1995). Stages of the policy process. In: McCool, Daniel C. Public Policy Theories, Models, and Concepts - An Anthology. PRENTICE HALL, Upper Saddle River.

Santos, R. S., \& Varella, M. D. (2016). Uma análise conceitual da dignidade como fundamento dos direitos humanos e sua invocação em decisões do STF e da CIDH. Revista $\begin{array}{llll}\text { Opinião Jurídica } & \text { (Fortaleza), } & \text { 14(19), } & \end{array}$ https://doi.org/10.12662/2447-6641oj.v14i19.p171-194.2016

Sunstein, C. R. (2009). A constitution of many minds: why the founding document doesn't mean what it meant before. Princeton University Press. https://doi.org/10.1515/9781400829927

Cancado Trindade, A. A. (1990). A questão da implementação dos direitos econômicos, sociais e culturais: evolução e tendências atuais. Revista Brasileira Estudos Politicos, 71, 7.

Trindade, A. A. C. (1997). Dilemas e desafios da Proteção Internacional dos Direitos Humanos no limiar do século XXI. Revista Brasileira de Política Internacional, 40(1), 167-177. https://doi.org/10.1590/S0034-73291997000100007

Vieira, O. V. (2008). Supremocracy. Revista Direito GV, 4(2), 441-463. https://doi.org/10.1590/S1808-24322008000200005

\section{Copyright Disclaimer}

Copyright for this article is retained by the author(s), with first publication rights granted to the journal.

This is an open-access article distributed under the terms and conditions of the Creative Commons Attribution license (http://creativecommons.org/licenses/by/4.0/). 